\title{
Common Property and Natural Resources in the Alps: The Decay of Management Structures
}

Local-authority and collective forms of ownership still tend to dominate in the Alpine regions. This article concentrates on collective ownership or common property in the Alps and poses the question as to its importance with respect to the sustainable use of natural resources in the mountain regions. The concept of common property or collective ownership is explained in the first part of the article and the advantages and disadvantages of this ideal type of regulatory system, at least as presented in the literature, are explored briefly.

Based on empirical examples in Switzerland, the second part of this article shall demonstrate how common property regimes have undergone a change, despite the basically unchanging nature of property rights. This article and especially the chosen cases question the studies carried out by Netting (1976; 1981), who examined alpine, meadow and forest management in the Valais village of Torbel. Netting demonstrated that a differentiated collective property order for forests, meadows and alps is no historical anachronism and can produce entirely valid results. Chapter three is, therefore, concerned with recent trends and emerging management forms for forests, water courses and alps.

\section{Common Property}

A distinction is made in the literature between four ideal types of property rights arrangements. An arrangement is understood as a comprehensive co-ordination mechanism which regulates the obligations and rights of users vis a vis a resource (access, removal, use, sale, control, monitoring, conflict resolution etc.). In the case of private property, individuals have rights of use and sale. If title is held by local authorities, cantons or the state, it is a case of state ownership. In what is referred to as "open access", there is no clearly regulated right of title; everyone has free access. In contrast, in the case of "common property", right of title is in the hands of a group which has established regulations governing use and excludes non-group members from use of the resource. '"Common property' or 'common property regime' is used to refer to a property rights arrangement in which a group of resource users share rights and duties towards a resource" (McKean/Ostrom 1995: 5).

For a long time, common property and open access were treated as equivalent in theory and this, in conjunction with Hardin (1968), resulted in the erroneous conclusion that collective ownership is also connected with the destruction of natural 
resources. Hardin describes the fate of freely accessible pasture land on which anyone can graze their animals in the "Tragedy of the Commons". Here destruction is preprogrammed as each herdsman profits - on the basis of individual calculations - from grazing more than the optimum number of animals on the pasture and the cost of overuse is carried by all users. Ostrom et al. (1999) have, however, drawn attention to the fact that the concept of common property is, in fact, incorrectly applied here and this situation should actually be described as one of open access. Moreover, they draw attention to the fact that this model's pessimistic prognosis should only be understood against the background of the specific model assumptions, such as a finite supply of resources, homogenous users, individual utility maximisers and the reluctance to introduce institutional change.

What should be noted with respect to the above-described typology is that a wide variety of property rights arrangements exists which actually constitute mixed forms. Moreover, the regime, i.e. the social institution, must be clearly distinguished from the characteristics of natural resources - to add to the confusion, the concept "common property resources" is used in the English literature.

The potential for the destruction of a resource does not only depend on the social institutions selected. It is also strongly dependent on the nature of the goods and services and the situation with respect to action. Goods, for which the exclusion principle for beneficiaries is not applied, and for which rival uses exist, present particular problems. The cost of the creation of regulations for the exclusion of potential users is relatively high in this instance and this, naturally, prompts the users to overexploit the resource. Ostrom refers in this context to "common pool resources". In addition to the pattern of the "Tragedy of the Commons" and the characteristics of goods as possible explanations for the degradation of resources, the economics literature refers to external effects, non-defined property rights and the prisoner's dilemma. To put it rather simply, these approaches share the basic idea that due to individual actor interests and the associated optimisation of use, the freerider problem becomes an obstacle to the socially desired production of public rules and goods. For nobody can be excluded from the use of the collective goods once the goods in question have been produced and thus it is impossible to find a voluntary producer. However, Feeny et al. (1990: 12) draw attention to the fact that "... complex interactions among characteristics of the resource, the property rights regime and other institutional arrangements, and the socio-economic environment contribute to the degree of management success".

What is the advantage of common property? Common property regimes represent a form of regulation whereby the yield or benefit flow is divided up and distributed but the stock of the resource is not. Corresponding social regulations are particularly desirable in those cases in which the resource can be more efficiently managed in its entirety (substantial returns to scale through the management of a large area or the construction of infrastructure). This also applies if it is not possible to divide the resource (e.g. stratosphere, sea) and in cases involving mobile stocks distributed over a large area. Uncertainty with respect to the localisation of productive zones can also, for example, represent a further reason for the application of collective ownership. If 
there is a considerable variation in yield within a region, it is easier to distribute and sustain the risk through shared use. Moreover, externalities can be internalised through shared use. In many resource systems, use in one area affects productivity in another. If, for example, intensive farming is practised in one area it can result in the heavy pollution of ground water in neighbouring areas or relief in other regions. Shared management counteracts these negative effects. Although at an initial glance, it would appear easy to divide forests, large management units are necessary for the production of services such as biodiversity, protection and ground water reservoirs. The same applies for timber production.

Despite pessimistic predictions for the use and preservation of common pool resources, recent research has shown that collective ownership can make an important contribution to their sustainable use. Ostrom has formulated design principles for robust institutions based on several hundred case studies which examined natural resource use regimes (Ostrom 1990; Ostrom 1998). These design principles take the form of eight operational rules which have emerged over the decades and which are mainly applied at local and regional level. According to Ostrom, the primary concern in the production and use of collective goods is (1) to clearly regulate the rights of user groups and to formulate the boundaries of the collective goods in unmistakable terms. If this is not done, those who invest in the building of institutions will not be rewarded with sufficiently high profits due to the action of free riders. (2) It is also necessary to define by means of regulations governing the use of the resource, which are tailored to specific local conditions, who is entitled to use a resource, the quantities they can consume, the times at which they can use it and the technology they can employ. Beneficiaries who are affected by general regulations should also be able to participate in the introduction of (3) adaptations to the rules. (4) Compliance with the rules must also be monitored and (5) failure to observe them sanctioned. The studies also showed that the cost of monitoring and sanctions is relatively low for long-lasting institutions. This can probably be explained by the influence of social norms whereby failure to comply results not only in the application of the relevant sanctions but also in social ostracism. The remaining principles include the relatively (6) low cost of conflict resolution mechanisms, often at local level. The institutions developed in this context should not be questioned by state authorities but (7) recognised by them and given the corresponding legitimisation. Moreover, it should be noted that these governance activities are embedded in a multi-layered system - Ostrom also refers in this context to (8) "multiple layers of nested enterprises".

\section{Transformation of Property Rights and Management Structures}

A long established tradition of common property regimes exists for the management of forests, Alpine pastures and water. The examples described below demonstrate how property and use regimes have changed as a result inter alia of social development. 


\subsection{Traditional Use and Transition in Management Structures on the Brischern Alp in the Canton of Valais}

Brischern has been chosen as an example for the change or decay of the common management regime in the Alps. The Brischern Alp (i.e. Alpine pasture), which lies in the local authority area of Mund in the Canton of Valais, is approximately 165 ha in size and is mainly located above the forest zone at a height of ca $2000-2500 \mathrm{~m}$ above sea level. The pasture is managed by two independent alp co-operatives ("Alpgeteilschaften"). This account deals solely with the main Eggerberg section and presents its traditional use and the transition in the use regime.

\section{The traditional structure of the use regime}

In this context, traditional use should be understood as the property and use regime that passed unchanged from one generation to the next and remained valid up to the 1950s.

The Brischern Alp is the property of an alp co-operative. The property rights have been defined in the co-operative statutes since the Middle Ages. In addition to the statutes, regulations also exist which govern the alp, water and the alp huts and define their use in greater detail.

A11 natural persons who have rights to the Brischern Alp are members of the cooperative and hence also enjoy right of use. The minimum share is 1 hoof("Klaue"), which corresponds to $1 / 8$ cow right ("Kuhrecht"). Rights to the alp are transferred through sale or inheritance. The co-operative members are obliged to participate in the joint operation ("Gemeinwerk") of the alp. The joint operation represents community service for the maintenance of the alp. A general assembly is held every year for the election of the alp commission, stewards ("Alpvogte") and auditor ("Revisor") and voting on changes to the statutes. The alp commission is the co-operative's managing body and it is responsible for the implementation of regulations. The auditor compiles the annual financial statement and presents it for approval to the general assembly. The main function of the stewards is to supervise the alp and organise the joint operation.

Although they have no rights, the dairy maids play a central role at operative level. They ensure that the summer grazing on the alp is carried out in an orderly fashion. Their tasks include tending to the cattle, processing the milk and taking care of children. The inhabitants of the villages represented on the alp place their cattle under the care of the village dairy maids. At the end of the summer, the Teilmann (literally "distributor") distributes the yield among the farmers whose cattle grazed on the alp. Each village has its own Teilmann².

The alpine meadows on this alp embody an important element within the land used on a co-operative basis. While they belong to the co-operative and also represent a common property effect, the authorised users enjoy possession of an easement which

\footnotetext{
Volken (forthcoming), The Use of Alpine Pastures and Forests in Transition.

Verbal statement by Anna Zimmermann-In-Albon and Elisa Theler-In-Albon, who was a dairy maid on Brischern until 1948, 16.3.2000.
} 
gives them exclusive rights to the hay harvest (Antonietti 1988: 120-121) ${ }^{3}$. Outside the mowing and hay-making periods, the land is common property and used as pasture.

The alpine huts were private property from the outset although the land on which they are built belongs to the co-operative ${ }^{4}$.

In summary: the traditional use system can be described as a system of "checks and balances". The control mechanisms, which have been based on the statutes from the outsets and govern the co-operative use to the last detail, are very striking. They are an expression of the strong dependency of a society whose fate is bound up with mountain agriculture, for better or worse. Through its use of democratic elements, the alp co-operative is based on broad consensus. The strict organisation with the general assembly, alp commission and the stewards guarantees the small-scale division of power. It is also interesting to observe how the organisation of the alp is concentrated on the village unit and how strong the distrust of everything "outside the village" is.

\section{The transition of the use regime during the last century}

The following table shows the development of cattle grazing practises on the Eggerberg side of Brischern over the last century:

Table: $\quad$ Use of the Eggerberg Side of the Brischern Alp

\begin{tabular}{|c|c|c|}
\hline Year & No. of livestock & Source \\
\hline 1900 & 82 & $\begin{array}{l}\text { Schweizerische Alpstatistik (Swiss Alpine Statistics) } \\
\text { (SAV 1900) }\end{array}$ \\
\hline 1940 & $\sim 100$ & Alpkataster (Alpine Register) (EVD 1968) \\
\hline 1968 & 23 & Alpkataster (EVD 1968) \\
\hline 1996 & 7 & $\begin{array}{l}\text { Sömmerungsbeitragsgesuch (Application for summer } \\
\text { grazing) }\end{array}$ \\
\hline 1997 & 10 & Sömmerungsbeitragsgesuch \\
\hline 1998 & 13 & Sömmerungsbeitragsgesuch \\
\hline 1999 & 8 & Sömmerungsbeitragsgesuch \\
\hline
\end{tabular}

This marked reduction in cattle raising alone, at least at operative level, demonstrates the significant transition. During the War years, there were six or seven milk maids tending to the cattle on the Eggerberg side of Brischern. In 1966, there was only one milk maid and in 1969 the last milk maid spent a summer on the alp. Since 1970, only one family from the neighbouring community of Mund has been availing of the alp (Jossen 1989: 158). This family processes the milk itself, mainly for its own use (Schmidhalter 1998: 9). The end of regulated operation of the alp by the milk maids also marked the end of the "joint operation" by the co-operatives. The resource was effected by this neglect. Large parts of the former forest meadows and the other meadows are now covered with shrubs and bushes. These meadows now have little

And verbal statement by Edmund Hutter, former local-authority president of Mund, 17.3.2000.

Verbal statement by Edmund Hutter, 17.3.2000.

s Verbal statement by Norbert Zimmermann, President of Brischern Alp Co-operative, 11.5.2000. 
value for grazing and can at best serve as extensive beef or sheep pastures (Schmidhalter 1998: 5).

The formal regime remained stable throughout the period of transition. The last statute revision was authorised by the general assembly in $1998^{6}$. The content of these statutes still bears witness to very traditional use. Adaptation has, however, taken place in that a lease agreement between the general users and the alp co-operative has been added to the regime. This gives the lessor exclusive use rights and infringes on the use rights of the co-operative members.

How can this transition in traditional use interests be explained? Up to the middle of the last century, the management of alpine pastures embodied an essential part of the annual cycle of an agricultural system which was predominantly self-supporting (Kaufmann 1965). The rise of industry in the post-war era increasingly attracted people away from agriculture while others were lost through emigration as land became scarce commodity for the growing population. Full-time farmers were replaced by part-time farmers who found employment as seasonal workers in hotels for a few weeks or worked as low-skilled and shift operators in factories but continued to farm the land inherited from their parents, albeit on a reduced scale ${ }^{7}$. The subsequent transition from an industrial to service society saw the younger generation turn away from agriculture. Whoever still finds the enthusiasm to engage in farming as a sideline does so as a hobby and this is referred to as "leisure farming" (Lerjen 1998: 22). The self-sufficiency of extended families is no longer the main priority and the operator's personal identity has taken over as the main focus: there is prestige attached to caring for animals and tilling one's old land. The transition to leisure farming was marked by the withdrawal of women from farm work. This simultaneously marked the end of large-scale livestock raising and concern with the fulfilment of basic family needs and the shift in emphasis from the extended family to the nuclear family.

\subsection{The Growth in State Influence on Forest Management Structures}

The history of Swiss forests is the history of increasing state intervention and the emergence of stable property rights structures during the 20th century. First, we will give a short overview of the development of property and use rights up to the early 20th century. In the second part, we will argue that forest management has been increasingly dominated by state intervention, despite the constancy of ownership structures.

\section{The emergence of the existing ownership structure}

It is possible to trace the evidence of collective forest management in Alpine villages back to the Middle Ages and even earlier (Merlo 1995: 58). Forest was a key resource in Alpine villages; the local population made extensive use of firewood, berries, leaves and forest pasture land (mainly for goats) as well as relying on forests for protection

\footnotetext{
Verbal statement by Norbert Zimmermann, 23.5.2000.

Sociologists try to explain the reason why men and women took on this dual committment in terms of an "inneralpine autarky complex", i.e. the urge for self-sufficiency of the extended family and "personal affection" (Lerjen 1998: 22).
} 
against avalanches and landslides ${ }^{8}$. Shared ownership was thoroughly commonplace a piece of land could be the property of a lord, the right of investiture of a man and a farmer's estate. Although ownership rights were only introduced later with the advent of the liberal revolution, in many cases, locals defined the use rights that regulated the use of forests and forest products as early as the 16th century. These use rights usually formulated the property rights arrangements which are still in force to the present day and led to many corporately managed resources or "common property regimes", whereby some locals shared exclusive use rights to the most important products such as firewood or forest pasture land. However, other forests were not corporately managed: many were open to all (open access) or were tributary to a landlord or a city and, for most places, either different (but not contradictory) use rights were in place, or some forest were corporately used and others open to all.

The main impulse behind the establishment of corporate structures was the fact that it enabled locals to defend their acquired rights against new residents (Schuler 1998: 3.6/2). Whereas in the Swiss plains, access to the corporations was usually only possible by birth into a privileged local family, the corporations in the Alpine forests were open to the owners of farms; this means that the buyer of a farm automatically acquired the use rights for the forest products. The corporations usually forbade and sanctioned the trading of firewood with other non-members as well as the use of wood outside of the boundaries of the corporations or communes. Finally, all uses were banned in some mountain forests which were important for protection against avalanches and landslides.

As a result of energy-intensive commercial activities, the forest cover in Switzerland diminished during the 16th, 17th and 18th centuries and harvesting in mountain forests near rivers increased the instances of damage from landslides and avalanches. This gave rise to massive disturbances in the hydrological system and increased flooding in the Swiss plains. The harvested trees in the mountain forests were also less likely to be reforested as saplings were a favoured food source among the goats herding in the Alps.

The way to more effective regulations was paved at the onset of the modern age with the newly established concept of liberal and absolute ownership. Ownership was perceived as exclusive in association with freedom at the cost of lawfully-acquired rights (Below/Breit 1998). Even more importantly, most of the forests became state property after Napoleon's invasion of the Swiss federation in 1798. Shortly after the declaration of the Helvetic Republic in 1798, the cantonal woodlands and monasteries were nationalised, as a result of which more than $60^{\prime} 000$ hectares of land came into the ownership of the Swiss government. With the Act of Mediation of 1803, however, ownership of the named woodlands was returned to the monasteries and cantons. A Swiss liquidation commission ensured that the towns retained the volume of forests needed to cover their timber requirements. The remaining forests were given to the cantons as state forests (Kissling 2000). 
The situation in the first half of the 19th century was dominated by the proponents of early liberalism who strove to manage forests on the basis of market rules and predicted high prices and market equality. This led to the relinquishment of the multilayered feudal property rights at the expense of the lower classes, a development which resulted in corresponding abuses of the law. In political discourse, existing use practices were identified as the causes of natural disasters and flooding (e.g. in 1834 in the cantons of Graubunden, Tessin, Valais and Uri) and this gave rise increasingly urgent calls for the state to restrict property rights (Schuler 1998: 3.11/4). This trend was further intensified by the emergence of a coalition between hydrologists and foresters and the foundation of the Swiss Forests Association \{Schweizerischer Forstvereiri).

\section{Increasing state intervention based on highly regulated forest policy}

In the 19th century, the historical background shows how state intervention and, specifically, cantonal and national regulations found their legitimisation in the inadequate management of local collective authorities. A virtual wave of cantonal forest legislation was initiated in the late 1830s. The failure of this legislation and the continuing overfelling of mountain forests subsequently prompted the state to commission a study on the mountain forests. The main trigger for the embedding of federal competencies "in the general supervision of water infrastructure and forest police in the high mountain regions" (Art. 24 BV (Swiss Constitution) 1874) was renewed major flooding in the mountain areas in 1868. The decision to establish a Swiss Forest Inspectorate was made in 1874. However, the aims of national forest policy remained unfulfilled. In 1902, the Forest Police Law was revised and extended to cover all woodlands. Despite various revisions, the basic content remained unchanged, with the exception of promotional measures which continued to be developed over the decades.

\section{Figure: Ownership offorests (whole Swiss area in hectares)}

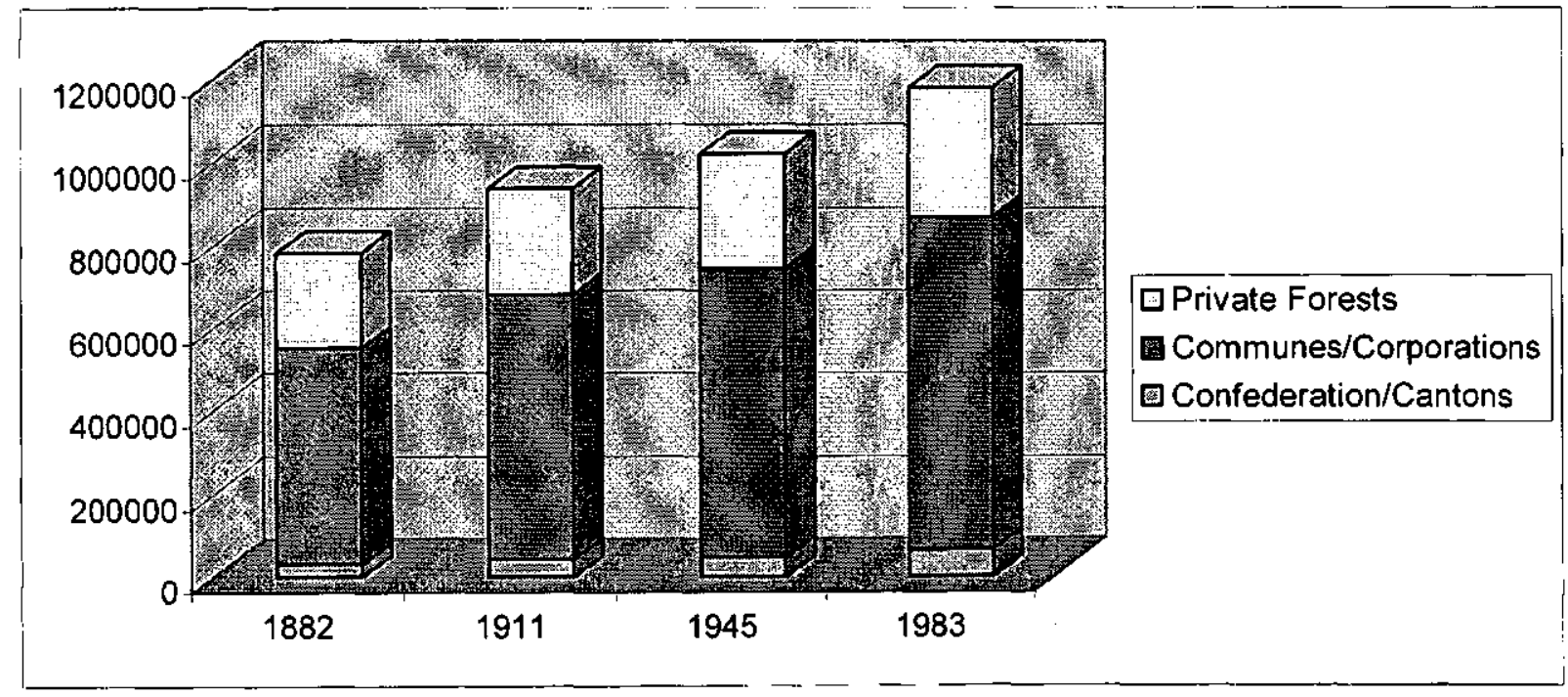

Source: Ritzmann (Table 1.44), data from Landolt 1884 and annual forest statistics (BFS/BUWAL 1998) 
As the graph shows, the ownership structures of the whole Swiss area remained largely unchanged for more than a century. About $30 \%$ are private forests, but only $15 \%$ of mountain forests in Switzerland are actually privatised; approximately $40 \%$ of mountain forests are owned by local authorities and $2 \%$ by the State and cantons. $37 \%$ are owned by citizens' associations (boroughs) and $6 \%$ by co-operatives and corporations. This could be explained inter alia by the authorisation procedure for the division of forests which has been in operation since the turn of the century for public forest and since 1945 for private forests as well as the subsidising of plot consolidation from 1945.

Although a major proportion of forest remains in collective ownership (corporations, citizens' associations), it is important to note that, in Switzerland at least, their management has been strongly influenced by the state regulations. For almost one century, the preservation of the forest cover was the main official goal which was enforced by means of the strict legal definition of forests, the prohibition of deforestation, a ban on clear-cutting and mandatory compensation in kind for deforested areas. Owners were obliged to seek authorisation for the harvesting of trees. The increasing state intervention has culminated in the multiplication of subsidies in response to the Waldsterben since the mid-1980s (from SFr 60 million in 1984 to SFr 270 million in 1990). In addition to infrastructure facilities and forest preservation, financial support was provided for the maintenance and tending of Swiss forests. The growing financial support went hand in hand with the deteriorating financial situation of collective associations. Since 1987, public forest enterprises can no longer cover their expenses with the subsidies and income from sales of wood.

Zimmermann (1995: 82) makes the following observation on the canton of Tessin: "The Corporations own the forests, but the Canton with its financial and technical resources essentially manages them - directly or indirectly - according to state policy. Ironically, in the 1990s the common-property forests survive mainly because their 'inalienable' ownership by the Corporations is considered a 'guarantee' of these forests current and future ability to meet such social demands as stabilising and purifying the environment, maintaining biodiversity, and providing physical and spiritual recreation."

State influence and with it the dependence of forestry operations on state subsidies have increased significantly. As a result, independent management in collectives has diminished despite the fact that there has been no change in the formal property structures. With the supported of neo-liberal trends, such as new public management, this can result in the relinquishment of common property structures. An example of the decay of corporate structures is the consolidation of the borough ("Burgergemeinde") and the local authority ("Einwohnergemeinde") in the city of Lucerne?.

\subsection{Water Use Regimes in the Canton of Valais}

Traditional water use systems constitute an important component in the management of land in the Alps. Due to the low annual precipitation volumes and the nature of the

\footnotetext{
A popular decision took place in 1999 and the new merged organization will be put into action in 1 septembre 2000 (Verbal statement by the Forest Office of the city of Lucerne, 25.5.2000).
} 
geographical location, artificial irrigation was always necessary, particularly in the canton of Valais ${ }^{10}$.

In terms of understanding the necessity of artificial irrigation in this region, it is also worth mentioning that up to the correction of the Rhone at the beginning of the last century, the valley floor was uninhabitable. The population was forced to settle along the dry valley sides. The 19th century was characterised by strong growth in population; the population of Valais doubled between 1800 and 1928 (Crettol 1998: 6). It was, therefore, necessary to extend the agricultural production areas, and the development of irrigation systems had a key role to play here.

The traditional design and the transition of the water use systems are described below with reference to a specific man-made watercourse, the Bisse de Vex.

\section{The traditional design of the water-use regimes ${ }^{\prime \prime}$}

The suone (French: bisse, English: man-made water course) constitutes the mainstay of traditional water-use regimes. A suone is an irrigation channel which transports water from the glacier or stream to the fields, meadows, vineyards and fruit plantations $^{12}$. The use of the suone is comparable with the use of the common, although it constitutes a mixture of private and public property: the channel itself and the water are public property while the water rights and land irrigated by the suone are privately owned.

The co-operative is the most common form of administration for suonen. Examples also exist, however, whereby the municipal authority takes charge of the construction and maintenance of the suone. The regulations governing the suone co-operative are extremely precise and strict and contravention is heavily sanctioned. In addition to the definition of sanctions, the suone regulations also outline the allocation of the various water rights, the division of the irrigated area into quarters and sectors, the temporal cycle on the basis of which the water changes (water cycle), the start of the water cycle, the timing of the annual maintenance work and the general organisational provisions. The maintenance work is carried out by members of the community as part of their Frondienst or service to the community. The water use rights are frequently associated with a specific site, hence the land cannot be sold without water rights.

In the suone system, a day is generally divided into three or four irrigation periods of equal length which are generally defined on the basis of time, although in rare cases they are governed by the position of the sun and shadow. The irrigation season always begins on the same day of the year, irrespective of whether the water is needed or not. A water cycle or tour covers the period taken to irrigate all of the fields. The meadows

10 The main valley in Valais runs in a north-east-south-west direction. The valley is enclosed on both sides by the Valais or Berne Alps. This gives rise to the rain shadow effect and warming effect due from the perpendicular solar radiation on the mountain flanks. Annual precipitation volumes of approximately $600 \mathrm{~mm}$ are not unusual (Reynard 1997: 51).

"Cf Bratt 1995.

${ }^{12}$ An inventory of all of the suonen in the Canton of Valais in 1993/94 identified a total of 376 with a total length of ca. $2000 \mathrm{~km}$ of mains piping. To this is added the ca. $25,000 \mathrm{~km}$-long secondary network along the fields and meadows (Werlen/Aufdereggen 1994). 
are irrigated from four to five times per year, the vineyards twice and the irrigation is generally completed by mid-August.

A suone co-operative is governed by the suone commission and its commission president. The commission, which generally rules for four years, appoints the Wasservogt or "water steward" who is responsible for the distribution of water rights, the appointment of individuals for the construction of the suonen and their supervision. The co-operative generally meets twice each year, in spring and in autumn. Elections for the commission, president and Wasservogt are held at the meetings as well as discussions and votes concerning changes to the suone regulations.

\section{The transformation of the use regimes in the 20 th century}

Most of the irrigation network that exists today is relatively recent in origin and was constructed in the late 19th and first half of the 20th centuries. During this period, most of the suonen were either rebuilt or systems originating from the Middle Ages were comprehensively updated. Numerous suonen were completely restored, in particular after the First World War and in the 1930s (Werlen/Aufdereggen 1994: 21).

The development of the irrigation system in Valais in the 20th century is characterised by two general trends: technical progress led to the improvement of the suonen and traditional suonen were increasingly replaced by underground irrigation systems and sprinkler systems (Werlen/Aufdereggen 1994: 21). From around 1900, the federal and cantonal authorities introduced subsidies for the construction of suonen and financial support was also later provided for maintenance work (Crettol 1998: 7). The foundation of the cantonal Office for Land Development (Bodenmeliorationsamt) created the basis for the improvement of the canton's infrastructure, including the suonen.

After the Second World War, water was the driving force behind the social and economic shift away from a predominantly agricultural society to a society focused on industry and services. Farmers began to work - initially part-time and later full-time in industry and tourism. Despite the better education of young farmers, the improved use of land and other developments, mountain farming failed to establish links with the intensive farming emerging in the lowlands. The continuous division of sites, promoted by the inheritance laws and strong resistance to the consolidation of estates, favoured the movement away from the primary sector (Werlen/Aufdereggen 1994: 24). Those who stayed with agriculture came under strong pressure to rationalise and this had a significant effect on the demise of the traditional irrigation systems. Technical and economic development meant that the community gradual relinquished its central role in the organisation and maintenance of the irrigation system in Valais. The functioning of the modern irrigation systems does not depend on the strict observation of regulations for their use and they do not require maintenance work by the community.

Over the past twenty years, however, it has been possible to observe a veritable renaissance of the suonen. This is a reflection on the one hand of the recognition of the importance of agriculture for future development and the rediscovery of the suonen as 
a traditional feature of the landscape with significant tourism potential. The definitive impulse came in 1982 with the launch of the campaign "La Suisse pas a pas" ("Switzerland step-by-step") by the Swiss Tourism Association (Schweizerischer Tourismusverband) (Reynard 1997: 52). In 1996, the Valais Tourism Association \{Walliser Tourismusverband) and the Association of Valais Hiking Trails (Vereinigung Walliser Wanderwege) jointly published a guide to the best known routes along the suonen which are particular popular due to their flat course and proximity to the water. Some of the suonen are now being restored by interested groups.

\section{The Bisse de Vex}

This transition in the use and importance of the suonen is clearly demonstrated by the Bisse de Vex (Reynard 1998: 197-198). This suone originated in the year 1453 and is $12 \mathrm{~km}$ long. It was operated for approximately 500 years until 1971 when its maintenance was no longer feasible. A committee was established in 1989 whose aim was to bring about the restoration of the suone. To minimise costs, the work was carried out with the help of the local civil defence organisations, the army, unemployed, prisoners and school children. The project was financed by the Department of Public Services, the Office for Land Development, the Association of Valais Hiking Trails, the Swiss Landscape Fund (Schweizerischer Landschaftsfonds), the French Swiss Lottery (Loterie romande) and contributions from the committee.

\section{Conclusion}

The selected examples demonstrate that common property structures are in transition in Alpine regions. Social developments have resulted inter alia in the demise of existential dependence on functioning collective systems which have hence relinquished their significance. Intact cooperative use systems which still enjoy state support may well exist. Some of these, however, already show signs of decay and others have been completely abandoned (e.g. the suonen). It is, however, possible to observe initial attempts at the establishment of alternative self-organised structures (newly-formed private agencies/collaboration between cooperatives and private entities) for the introduction of new uses (e.g. tourism) to certain common pool resources. In any case, the decay in management structures arising from the transition in agricultural structures should be studied and new options examined which provide a response to the abundant areas and the loss of traditional management forms.

Antonietti, T. (1988): Eggerberg und sein Triel - ein bduerliches Gerdt in der dorflichen Erinnerung. Mengis Druck und Verlag, Visp, 167pp.

Below, S. v.; Breit, S. (1998): Wald - von der Gottesgabe zum Privateigentum: Gerichtliche Konflikte zwischen Landesherren und Untertanen um den Wald in der fruhen Neuzeit. Lucius \& Lucius, Stuttgart, 339pp.

BFS/BUWAL (1998): Wald und Holz: Jahrbuch 1997. Bundesamt fur Statistik/Bundesamt fur Umwelt, Wald und Landschaft, Neuchatel, 163pp. 
Bratt, G. (1995): The Bisses of Valais: Man-made watercourses in Switzerland. Eigenverlag des Autors, Buckinghamshire, 144pp.

Créttol, M. (1998): Gestion et préservation des bisses en Valais. Travail de diplôme MPA, IDHEAP, Genève, 79pp.

EVD (1968): Land- und alpwirtschaftlicher Produktionskataster, Gemeinde Mund. Eidg. Volkswirtschaftsdepartement, Bern, 1-35.

Feeny, D.; Berkes, F.; McCay, B.J.; Acheson, J.M. (1990): The Tragedy of the Commons: Twenty-Two Years Later. Human Ecology 18: 1-19.

Hardin, G. (1968): The Tragedy of the Commons. Science 162: 1243-1248.

Jossen, E. (1989): Mund - das Safrandorf im Wallis. Rotten-Verlag, Brig, 423pp.

Kaufmann, B. (1965): Die Entwicklung des Wallis vom Agrar-zum Industriekanton. Polygraphischer Verlag AG, Zürich, 173pp.

Kissling-Näf, I. (2000, forthcoming): Forests as Common Property in the Alps. In: Price, M. et al. (eds.): Mountain Forests (working title). IUFRO, Vienna.

Lerjen, H.-P. (1998): Vom Arbeiter- zum Freizeitbauern: Sozialgeographische Annäherung an ein Oberwalliser Phänomen im Einzugsgebiet der Chemischen Industrie in Visp 1970-1994. Diplomarbeit am Geographischen Institut der Universität Bern, 182pp.

McKean, M.; Ostrom, E. (1995): Common Property Regimes in the Forest: Just a Relic from the Past? Unasylva 46: 2-15.

Merlo, M. (1995): Common Property Forest Management in Northern Italy: A Historical and Socio-Economic Profile. Unasylva 46: 58-63.

Netting, R. (1976): What Alpine Peasants have in Common: Observations on Communal Tenure in a Swiss Village. Human Ecology 4: 135-146.

Netting, R. (1981): Balancing on an Alp. Ecological Change and Continuity in a Swiss Mountain Community. Cambridge University Press, Cambridge, 278pp.

Ostrom, E. (1990): Governing the Commons: The Evolution of Institutions for Collective Action. University Press, Cambridge/New York, 280pp.

Ostrom, E. (1998): Self-Governance and Forest Resources. Workshop in Political Theory and Policy Analysis, Bloomington: 1-28.

Ostrom, E.; Burger, J.; Field, C.B.; Norgaard, R.B.; Policansky, D. (1999): Revisiting the Commons: Local Lessons, Global Challenges. Science 284: 287-282.

Reynard, E. (1997): Réhabilitation de canaux d'irrigation de montagne à des fins touristiques. L'exemple des bisses du Valais. L'eau, l'industrie, les nuisances No. 213: 50-56.

Reynard, E. (1998): Gestion patrimoniale et intégrée des ressources en eau dans les stations touristiques de montage. Le cas de Crans-Montana-Aminona et Nendaz (Valais). Thèse de l'Institut de géographie de l'Université de Lausanne: 184-211.

Schmidhalter, M. (1998): Alpe Brischern - Bericht über die Alpung. Dienststelle für Landwirtschaft, Amt für Betriebsberatung, Sektion Visp, Visp, 14pp.

Schuler, A. (1998): Wald- und Forstgeschichte: Skript zur Vorlesung. Professur für Forsteinrichtung und Waldwachstum, ETH-Zürich, Zürich. 
SAV (1900): Die Alpwirtschaft im Oberwallis. Schweizerische Alpstatistik, Schweizerischer alpwirtschaftlicher Verein, Zehnte Lieferung: 101-102; 214235.

Werlen, Ch.; Aufdereggen, J. (1994): Suonen/Bisses. Bericht zum Inventar der Suonen im Wallis. Sion/Brig-Glis.

Zimmermann, R.C. (1995): The Common-Property Forests of Canton Ticino, Southern Switzerland: Relations between a Traditional Institution and the Modern State 1803-1994. Workshop in Political Theory and Policy Analysis, Bloomington: $1-91$. 